$2^{\text {nd }}$ International Conference on Advanced Research in Social Sciences \& Humanities

\title{
Some Aspects of the Translation Technique of Ancient works of Syriac Literature
}

\author{
Marika Chachibaia \\ Iv. Javakhishvili Tbilisi State University, Institute of Oriental Studies
}

\begin{abstract}
The study of works of old Georgian literature on the basis of their collation with the corresponding Syriac materials demonstrates one more aspect of the Oriental-Georgian literary relations and contributes to a considerable extent to the study of the literary contacts of the Christian population of the East. The presentation deals with the analysis of some problems of the relation of the Syriac text of the Life of Peter the Iberian - the central figure of Monophysites of Gaza - with the corresponding Georgian text and some issues of the translation technique. A comparative study of the Syriac and the Georgian texts of the above-mentioned work has not been conducted so far. In the process of comparative study of the Syriac and the Georgian versions a very interesting peculiarity is revealed. The dependence of all the main episodes on the Syriac text of the Life of Peter by Yohanes Rufus is obvious. It is clear how Macarios and Deacon Paul are "Georgianizing" the passages by Rufus. The translator of the Georgian version of the Life also "reconstructs" Peter's religious creed according to the period: Monophysite Peter in the Georgian text of the Life is represented as a Chalcedonian. The Monophysites threaten to kill him as a Chalcedonian, whereas in fact Peter was a Monophysite?!On the basis of comparative study of the Syriac and the Georgian texts of the Life it is possible to reconstruct the essential historical facts.
\end{abstract}

Keywords: Chalcedonian, Gaza, Georgian, Monophysite, Peter the Iberian. 